\title{
Predictive Path Modelling of Indicators of Secondary School Instructors' Affective, Continuance and Normative Job Commitment
}

\author{
Valentine Joseph Owan \\ Department of Educational Management, \\ Faculty of Education, University of Calabar, \\ Calabar-Nigeria.
}

DOI: https://doi.org/10.36941/jicd-2021-0015

\section{Abstract}

There is a growing body of literature investigating the impact of retraining and motivation on employee work efficiency. However, little seems to be understood about the effects of employee placement on the commitment of teachers to their jobs. To the best of the researcher's awareness, the partial and composite impact of staff placement, retraining, and motivation on the three aspects of job commitment (affective, continuance and normative) among secondary educators have scarcely been examined. This research was intended to fill this vacuum by using a predictive path modelling approach to analyse the association between these endogenous and exogenous variables. A random sample of 500 secondary school principals was surveyed using two forms of questionnaires. Collected data were analysed and formulated hypotheses tested using Path and multiple linear regression analyses, with the aid of Amos and SPSS packages. Findings indicated that staff placement and motivation were highly predictive of instructors' commitment (at the affective and continuance dimension), but not at the normative dimension; Employee dedication in the three dimensions was not predicted by personnel retraining, but it did result in employee attrition; workers retraining only increased teachers' work commitment when it was augmented with placement and motivation. The combined effect of staff placement, retraining, and motivation was statistically significant in two dimensions of teachers' job commitment (affective and continuance), but not on the normative dimension. Based on these findings, policy and theoretical ramifications for effective instructional management, assessment, classroom practice, and future study are discussed.

Keywords: Affective, commitment, continuance, motivation, normative, retraining 


\section{Introduction}

One of the central obligations of secondary education is to adjust students' conduct, set them up for a useful living and the advancement of their psychological, emotional and psychomotor attributes. Instructors assume a crucial role in any educational system without which, instructional objectives cannot be accomplished (Owan \& Agunwa, 2019). For any educational programme to be adequately executed, instructors are profoundly vital which accentuate the requirement for them to be effective in their everyday delivery of academic obligations. For teachers to be effective in their service delivery, they must be highly committed to their job. Job commitment is "the total and whole-hearted dedication of staff to the policies, initiative, programmes, reforms and prospects of the organisation with the willingness to obey and follow all prescribed rules and regulations towards the realization of short- or long-term goals" (Owan et al., 2020, p.87). Thus, job commitment may be defined as the rate at which employees are willing to remain loyal in rendering their services to an employer.

Considering the unique roles teachers play in the education sector, it is quite unfortunate that regular observation, experience and research has uncovered that numerous secondary teachers exhibit a significant level of insufficient and unwholesome attitudes to work (Owan, 2018; Owan et al., 2019). Such ineffectiveness is reflected in poor punctuality, taking part in strife with school overseers, the unpredictable composition of lesson notes, poor record-keeping and unacceptable mentalities to work (Arop et al., 2018; Owan, 2018). These negative behaviours exhibited by instructors are crude, dishonest and opposing to the attainment of secondary education objectives, just as those of the teaching profession (Omorobi et al., 2020). An explanation offered for the perceived non-commitment of instructors has been attributed to the poor payment of salaries and other dues, irregular promotion and/or the absence of many workrelated motivating forces (Nwadiani, 2008; Owan, 2018). This has promoted job dissatisfaction and poor attitudes among many teachers (Udofia \& Ikpe, 2012).

Consequently, many educators consider teaching to be a vocation that has no esteem and which despises any acknowledgement from people in general. There is also a general public perspective that teachers, especially those in developing nations, are living slightly above average; teasing them that their rewards are in paradise (Nwadiani, 2008). However, notwithstanding the shortcomings of secondary school teachers, the researcher contends that there might be some other underlying factors that may affect the rate of instructional delivery beyond the few reasons offered above. In this light, this study has been designed to survey assocaition among three indicators (placement, retraining and motivation) and how they possibly impact teachers' job commitment in secondary schools.

This research is grounded on the three-component theory of Allen and Meyer (1990), which postulates that the job commitment of employees can be adequately measured in a tripartite form across the affective, normative and continuance dimensions. It was 
theorised that job commitment, as a general construct, can be studied more specifically three-fold. Affective, continuance and normative commitment were listed as the facets of employee job commitment (Allen \& Meyer, 1990). Affective commitment refers to staff inclination to an organisation due to the passion for their jobs and the sense of fulfilment derived from working with an organisation (Owan et al., 2020). This type of commitment is commanded by employees with emotional ties to an organisation. These ties may be unrelated to the remuneration employees receive for their inputs, but results mostly from employee passion and satisfaction for their job, organisation or both.

Continuance commitment reflects staff persistence to work in an organisation just because of the perceived dangers or hardship they stand to face if they decide to leave the organisation (Owan et al., 2020). This type of commitment is tied to the gains or remuneration employees receive from organisations that create a feeling that getting something better elsewhere is impossible or difficult. As a result, the rational option is to stay committed to the workplaces at hand. It can be reasoned that this type of commitment appears to be more temporal than affective commitment because employees who are driven by continuance commitment may leave an organisation if a good remuneration offer comes from elsewhere.

The normative commitment is the inclination of workers to an organisation based on prescribed rules binding the organisation and the employee (Biwott \& Kemboi, 2017; Owan et al., 2020), which puts pressure on workers to stay in an organisation (Peretomode \& Bello, 2018). Employees maintain a sense of obligation to organisations due to the contractual terms of the agreement (Owan et al., 2020). It follows that employees have no option other than to commit to the organisation while the contract lasts, their interest notwithstanding.

As illustrated in Fig.1, employees who feel that they are in an organisation because they have to, reflect that they are affectively connected to their jobs/organisation; those who refuse to leave an organisation because of their desires or with a clear motive, are exhibiting continuance commitment; while those who remain with an organisation because they feel/think that they must stay are normatively connected to the organisation.

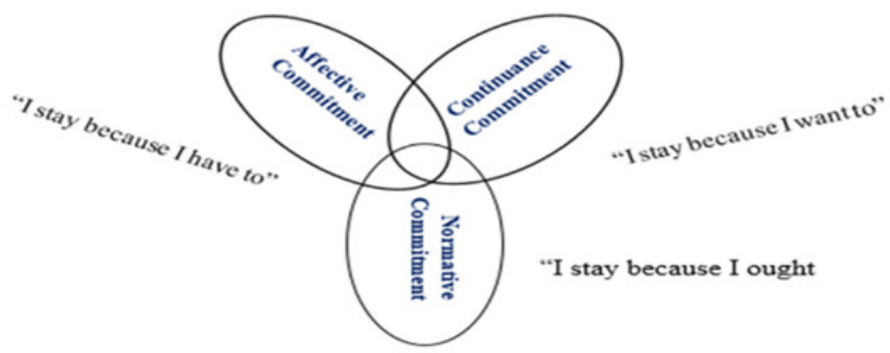

Figure 1: Three-way job commitment model. Source: Allen \& Meyer (1990) 
As shown in Fig. 1., A worker driven by the need to maximise remuneration may see a need to stop discharging service(s) if such incentives are unavailable or withdrawn. A worker who is emotionally tied to an organisation may persistently be willing to perform duties accordingly, with or without any form of motivation. These types of workers are not moved by the events happening around them but are motivated by the intrinsic satisfaction and joy they derive from mere working in the organisation. Lastly, many workers are likely going to stop performing duties if their contract tenure has expired even without being formally relieved of duty. They may also be reluctant to perform duties if they perceive that their employers as not keeping to the terms of the agreement.

The three-component theory of job commitment was adopted by the researcher to assess in specific terms, all the dimensions of job commitment rather than treating it wholly. Furthermore, the theory has implications for the present study because it explains the reasons why most workers are committed to staying or otherwise in an organisation. It is for this reason that this study was designed to assess these dimensions of job commitment in relation to three exogenous factors (staff retraining, placement and motivation). The aim is to determine the partial and combined effects of the exogenous factors on the response variable across the three dimensions.

\section{Literature Review}

\subsection{Staff placement and educators' job commitment}

Staff placement is the assignment of different employees to handle specific and welldefined tasks dependent on their capabilities and skills. Staff placement services are utilized to test, interview and prescribe qualified workers suitable in handling unique duties based on their competence, mastery or experience. Previously, a study has attempted to examine whether particular sorts of placement affect teachers' future performance but found that educators who were rightly placed to teach subjects they had mastery were more grounded with a strong educator coordinated effort and accomplishment gains (Ronfeldt, 2015). Less significantly, instructor maintenance was increasingly powerful at raising students' accomplishment (Ronfeldt, 2015). Another study revealed that there is a noteworthy connection between female instructors' placement and their attitude towards scholastic work and learners' academic performance (Okoroji \& Anyanwu, 2013).

It was hypothesized that, while various factors lead to students' excellent and bad academic success, the placement of numerous female educators in a school decreases instructor/school profitability and hence has a detrimental effect on students' academic results (Okoroji \& Anyanwu, 2013). Another research, which included 204 instructors from 32 senior secondary schools, discovered that determinant factors (teacher placement and planning) profoundly predict teachers' efficiency (Aja-Okorie, 20 I 6). 
Given the results and many others, the study indicates that the administration should include all compelling motivators to promote the function of secondary school teachers. A study assessed principals' administrative practices for promoting teachers' job performance and discovered that principals embraced the greater part of the staff professional developments and motivational practices (Ezeugbor et al., 2018). In any case, they neglected to support teachers for ICT capability in this innovation-driven world and outfitting of instructors' workplaces for a healthy work environment (Ezeugbor et al., 2018).

Considering that staff placement is a part of principals' duty during job allocation, the results of Ezeugbor does not give a clear indication of how placement was captured. An exploratory study of 50 respondents using a purposive sampling approach revealed, first, that there is no association between school administration and recently gathered knowledge and abilities of human resource managers (Hashmi, 2014). This result is in contrast with that of Sari and Sa'adah (2019) which found that work placement of teachers has a favourable and important impact on their job results. However, despite its positive effect on workers' execution of tasks, employee commitment does not significantly affect their performance (Khaerudin et al, 2018; Sari \& Sa'adah, 2019); implying that a committed employee can perform poorly on the job and vice versa. The various roles and strategies that are essential to advance educators' success are unknown to school leaders (Hashmi, 2014). Furthermore, the study reflected that a portion of the school managers place instructors wrongly to teach courses they do not have practical experience in dealing with (Hashmi, 2014). Therefore, the wrong placement of teachers may affect their work motivation and willingness to continue with an organisation. This may consequently lead to poor service delivery, truancy, and attrition.

\subsection{Staff retraining and educators' job commitment}

Staff retraining is a method of preparing, directing and equipping instructors with the important aptitudes, procedures, techniques and proper information required for viable substance conveyance, to draw out the absolute best in students (Agunwa et al., 2019). Employees should be given opportunities to improve their skills, experience, and capabilities by preparation and development initiatives (Cobblah, 2015). Teachers' development encompasses not just the preparation of new teachers who can provide education to learners, but also the retraining of current teachers available in schools (Aboyassin \& Sultan, 2017; Arop et al., 2019). The retraining of staff can be accomplished through updating educators' prior experiences using lectures, conferences, discussions, meetings, workshops, among other methods, in order to enhance their understanding and better address the needs of the public (Owan, 2018).

Research conducted by Cobblah (2015) used data from 860 library employees, personnel, and students from five Ghanaian colleges to analyze both quantitative and 
qualitative responses, using a mixed-method approach. Staff training and advancement initiatives were found to develop the skills, aptitudes, capabilities, and interactions of library staff in Ghanaian colleges, resulting in them being more viable and proficient in delivering library and information services to the college populations. Another research discovered a positive and minor relationship between instructors' in-service training participation, (such as seminars and workshops) and the performance of secondary school students in social studies (Essien et al., 2016).

In a related study, it was discovered that instructors who took part in an in-service training perceived apparently that the programme was helpful and valuable from numerous points of view (Romina, 2016). An explanation provided for this finding is that the preparation which the educators got emphatically influenced their instructing viability, with further evidence indicating that a strong positive relationship existed between in-service training and the instructional viability of teachers (Romina, 2016). Similarly, Gunu et al. (2013) found a favourable relationship between all of the variables in their study (training, development and organisational performance). The model synopsis demonstrates that all independent variables, which include training and development, accounted for $39.1 \%$ of the variance in the efficiency of formal organisations. Furthermore, just three variables were found to be important in the coefficient table: the contribution of organizations to training and growth, training and development frequency and the provision of incentive for optimal performance (Gunu et al., 2013).

According to a relational analysis, by Ocen et al. (2017), a moderate or strong positive correlation, that is proven to be statistically significant, exists between training and job commitment of employees; training and employees' job satisfaction; employees' job satisfaction and their commitment. The authors reported further that all the exogenous variables were responsible for $29.7 \%$ of the total variation in employee commitment. According to a study performed by Aboyassin and Sultan (2017) in the manufacturing sector, retraining has a positive impact on the service quality, profitability and job fulfilment of workers (which are indices of workers' success).

A study used data from 50 high-ranking employees to discover that organizational problems such as a lack of board funding for personnel recruitment and promotion plan limited staff training and improvement, with the latter (training and development) having a significant positive effect on the organization's workers' success (Degraft, 2012). Another study showed that workers on-the-job preparation schemes are bound to increase work capability than without; there is a strong clear association between inservice training maintained by the company and employees undergoing necessities after analyzing frequency data using the Chi-square statistical method (Tukunimulongo, 2016).

Based on the Social Exchange Theory, a researcher found that obvious access to training, provision of training social assistance, employee willingness to learn, and staff perception of the benefits of training are all strongly linked to job commitment in 
organisations (Bartlett, 2001). However, utilizing the three-component model of organisational commitment (as in the present study), it was discovered that the most grounded connections showed up between training and the affective dimension of employee commitment (Bartlett, 2001). The results further revealed that job fulfilment moderated the relationship between access to educational opportunities and the affective job commitment of workers (Bartlett, 2001). Various studies have also revealed a significant association (correlation) between training/retraining on staff job commitment in schools after adopting different methodologies (Mackenzie \& Nwafor, 2019; Naong, 2016).

\subsection{Staff motivation and teachers' job commitment}

Motivation is very essential in any institution because it increases the productivity of staff and boosts the chances of goal attainment in an effective way (Owan et al., 2018). There is a growing universal awareness that employee's motivation is a pre-requisite for the survival of any organization, be it in the private or public sector of the economy (Uso, 2011). Motivation is the mechanism by which a person's intrinsic efforts are focused toward different aims and priorities in his environment. It refers to those conditions, for example, acclaims, rewards, promotion, recognition, among others, that stir the enthusiasm of instructors in playing their obligations perseveringly (Omebe, 2005). Furthermore, motivation is described as something that inspires a person to carry out his or her duties in a predictable manner.

Through these definitions, it follows that motivation force people (teachers) to enjoy their role in teaching and changing learners' behaviours. Internal teacher motivation is inevitably linked to the degree to which principals use different techniques/practices to pique teachers' interest in participating in instructional procedures within the school setting. It is connected to principals ensuring that teachers have possessed the needed quality to keep the school climate-friendly and classrooms enticing (Ofoegbu, 2004). Therefore, the degree of motivational activities made available by school officials may have a negative or positive effect on educators' attitudes about their roles at school. In the present research, motivation is described as school principals use of influential driving forces (e.g., good communication, frequent meetings with students, recognition and encouragement for outstanding success, and maintaining teachers' well-being) to help instructors become viable and efficient in fulfilling their teaching responsibilities. As a result, motivation is considered in this study as a function of teachers' satisfaction or dissatisfaction with their jobs.

An extensive review of related empirical literature suggests that the topic of motivation and teachers' job commitment or effectiveness has gained wide attention. Such broad attention in the literature across multi-cultural perspectives is an indicator of its importance in the workplace. It was revealed through an empirical investigation that management can utilize various systems and strategies to rouse workers in the banking 
sector (Owusu, 2012). The analysis also proved that if the board removed incentive packages, it would have a real effect on workers' desire to perform delegated tasks. Since employees had the option to complete the bank's output pointers in terms of shops, credit recovery, competitiveness, and maintaining the banks' liquidity, the results of the inferential statistics demonstrate that there is a strong nexus between employee efficiency and corporate performance (Owusu, 2012).

The study of Uso (2011) revealed that staff promotion, job security, participation in decision-making and communication essentially impact instructors' efficiency among educators; although no explanation was given regarding why these variables were significant predictors of the dependent variable. In another research, a statistically significant relationship was recorded in the findings between teachers' motivation and institutional performance with job satisfaction providing the mediating link (Ali et al., 2016). In an explanation, it was revealed that 79.5 per cent of the variance in job performance was attributable to employee motivation; most notably, the quality of training received and instructional personnel research experiences influenced both motivation and performance (Kwapong et al., 2015). In this regard, motivation represents $79.5 \%$ of the variation in job performance, with the most noteworthy training achieved and the research experience of instructional staff impacting both motivation and performance (Kwapong et al., 2015).

This means that by enhancing their education and study experience, polytechnic lecturers in Ghana can boost their morale and job results. An analysis, based on a descriptive survey design, discovered that teachers' productivity in high schools was significantly dependent on the engagement pattern adopted by principals (Aja-Okorie \& Usulor, 2016). In both public and private high schools, the report discovered gaps in the degree to which principals maintain teachers' safety. In an exposition, the quality of working conditions was also unfavourable to certain workers, which represented undesirable behaviour among the employees (Nairuba, 2004). The study further found that pay scales and salaries have no direct impact on instructors' efficiency and that 70.9 per cent of respondents believed that incidental benefits such as stipends, acknowledgement, advancement, and lauds are still dependent on the availability of funds and the board's recognition (Nairuba, 2004). These advantages affected educators' exhibition when paid after completion of tasks. This is because, as previously reported, the quality of working conditions in some organisations was already very low, and this affected real school results. Great working conditions were in this manner, appropriate for all representatives' performance in any institutions. It is also known that the correlation between principals' motivational practices and teachers' performance exists to a weak extent (Nairuba, 2004)

\subsection{The present study}

Having explored the literature across the various sections of this study, it was discovered 
that unique findings abound. More specifically, the researcher discovered that there seems to be a few studies that have attempted to associate staff placement as a personnel management function to employee job commitment. This implies that many research efforts are plausible in this area to uncover underlying facts that are yet unknown. The current research was created to fill a void in the literature by exploring the relationship between teachers' job commitment (at the secondary education level) based on their placement. Much has been written about staff retraining and employee work engagement, with the majority of research showing that there is a strong association between job effectiveness and teachers' retraining (Aboyassin \& Sultan, 2017; Cobblah, 2015; Degraft, 2012; Gunu et al., 2013; Romina, 2016; Tukunimulongo, 2016). A study has looked at the correlation between teachers' retraining and the academic achievement of students (Essien et al., 2016).

All the studies on retraining have focused more on its connection with teachers' teaching effectiveness, with none linking staff retraining to job commitment. The researchers is, however, contending that teachers' job effectiveness and job commitment are not the same things. Because an effective teacher can be noncommitted (see Sari \& Sa'adah, 2019). Effectiveness tends to focus on doing things right, at the appropriate time and in line with expected standards. Job commitment, on the other hand, focuses more on employee willingness to stay in an organisation, which has implications on staff retention. Following the Allen and Meyer (1990) model of job commitment (earlier discussed), an employee can be doing things right but such staff may also be willing to switch the organisation if a better offer comes his way (continuance commitment). The current research appears to be the first of its kind to connect staff retraining to teachers' job commitment based on the facets of the threecomponent theory.

Lastly, it was observed that several studies exist on motivation on teachers' job performance or job effectiveness (Aja-Okorie \& Usulor, 2016; Ali et al., 2016; Kwapong et al., 2015; Nairuba, 2004; Owusu, 2012; Uso, 2011), but none have focused on the normative, affective and continuance aspects of job commitment. To the researcher's knowledge, only a little or nothing seems to be known about the connection of staff motivation on teachers' affective, continuance and normative commitment. Finally, this research seems to be the first to look at the impact of staff selection, retraining, and motivation on the three basic aspects of instructors' job commitment (affective, continuance, and normative). As a consequence, this research makes a unique contribution to the current body of literature, justifying its worthiness and relevance. This study was designed to answer the research questions and test the hypotheses captured in the results section of this report. 


\section{Methods}

\subsection{Research Design}

The correlational research design was used in this study, based on the quantitative research method. The nature (magnitude and direction) of the relationships between a series of variables is the goal of correlational research (Idaka \& Anagbogu, 2012). Under this design, the researcher has no control over this relationship; the relationship cannot be exploited because it exists naturally within a population or study. The association between variables may be positive, negative, or non-existent. Since the aim of this analysis was to explore independent variables such as staff placement, retraining, and motivation, as well as their respective and cumulative relationships to instructors' affective, continuance, and normative job commitment in secondary schools, a correlational research design was deemed reasonable.

\subsection{Study participants}

The research centred on 667 secondary school administrators (271 principals and 396 vice principals) from 271 public secondary schools in Cross River State, Nigeria. The researchers used a stratified random sampling method to assemble a sample of 500 school administrators (203 principals and 297 vice principals) from 203 randomly chosen schools. Three-quarters of the targeted population of schools, principals and viceprincipals were represented in this study.

\subsection{Instruments and measures}

Two main instruments were used for data collection including the "Staff Placement, Retraining and Motivation Questionnaire" (SPRMQ) and the "Job Commitment Questionnaire (JCQ)". The former (SPRMQ) was designed by the researchers and structured into two sections. Section A obtained respondents' demographic information while section B comprised 18 four points Likert scale items measuring staff placement (six items), staff retraining (six items) and staff motivation (six items). The latter (JCQ) was derived from an instrument titled "Job Commitment Questionnaire (JCQ)" which was designed by some scholars (Owan et al., 2020). There was no modification to the items in the original version of the JCQ, however, the researcher only adopted items measuring the three dimensions of employee job commitment (Owan et al., 2020). The TCQ comprised a total of 24 four-points Likert scale items with three sub-scales (affective, continuance and normative commitment; each having eight items).

The face and content validity of the instrument - SPRMQ was ascertained by five experts (Three educational managers and two psychometrists). The three educational managers were given separate copies of the SPRMQ to scrutinise, ensuring that items 
enlisted are broad enough to cover critical areas of the measures. The psychometrist ensured that an appropriate scale was chosen, the items were clear and free from vague and double-barrelled items. The researcher were able to improve the final version of the instrument that was used for data collection thanks to the recommendations and adjustments provided by these experts to the original version of the instrument. The SPRMQ's internal accuracy (reliability) was determined using the Cronbach alpha method, with a coefficient of.898 showing that the instrument was trustworthy. The face and content validity, as well as the factorial structure (construct validity) of the second instrument (JCQ), were already established by Owan et al. (2020). The reliability of three sub-scales of employee job commitment were determined using Cronbach alpha. Reliability coefficients of $.915, .941$ and .939 which were obtained for affective, continuance and normative dimensions of job commitment, attested that the instrument was reliable (Owan et al., 2020).

\subsection{Data collection and analysis procedures}

Ethical considerations were followed, first by seeking informed consent from the participants through the provision of full information about the research. Secondly, the researchers ensured that there was no form of bias based on gender, ethnicity or religious affiliation in being qualified to participate. Lastly, the author ensured that respondents take the survey in their respective schools without having to travel across distant locations to avoid issues of harm or injuries. Copies of the questionnaires were administered to the respondents and retrieved upon completion. Elicited responses were prepared, scored and coded accordingly while structural equation modelling (path analysis) and multiple regression analyses were used in answering the research questions and in testing the null hypotheses (where applicable).

\section{Results}

\subsection{Research question one}

How does staff placement influence secondary school instructors' affective, continuance, and normative work commitment? Based on the evidence presented in Fig.2, it was discovered that staff placement contributed $18 \%, 20 \%$ and $1 \%$ to the total variance in secondary educators' affective, continuance and normative job commitment respectively. Staff placement contributed more to the variance of teachers' continuance commitment before affective and normative commitments. By implication, the remaining $92 \%, 80 \%$ and $99 \%$ of the total variance are possibly explainable by other predictors not included in the model (see Fig.2). 


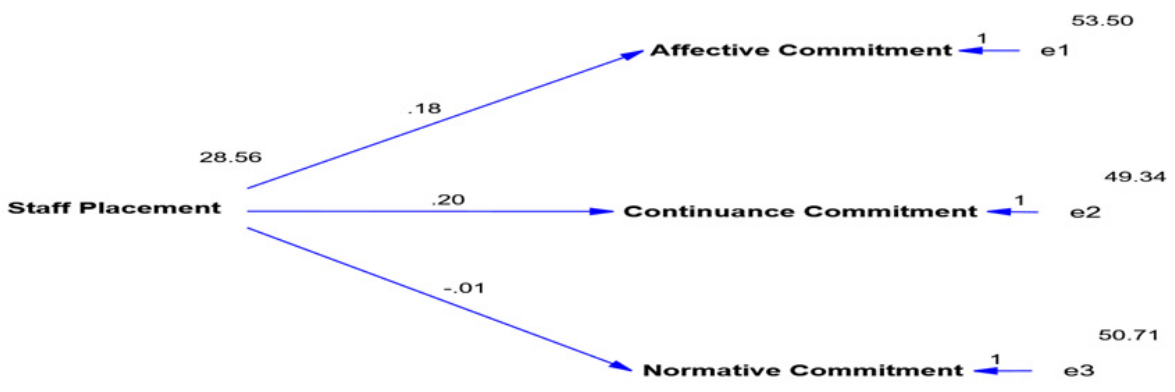

Figure 2: Path diagram showing the contribution of staff placement to secondary school instructors' job commitment across the three dimensions

Source: Author's computation

\subsection{Research question two}

How much of the variation in secondary school instructors' job commitment (across the three dimensions) can be clarified by workers retraining? The results presented in Fig. 3 reveals that staff retraining accounted for the total variance in secondary educators' affective job commitment by $3 \%$; continuance job commitment by $1 \%$; normative job commitment by $3 \%$. This indicates that out of the three dimensions of teachers' job commitment, staff retraining explained a higher percentage of variation in affective and normative dimensions than in the continuance dimension. This result implies that about $97 \%, 99 \%$, and $97 \%$ of the remaining variance in teachers' affective, continuance and normative commitment could be explained by other independent variables except staff retraining.

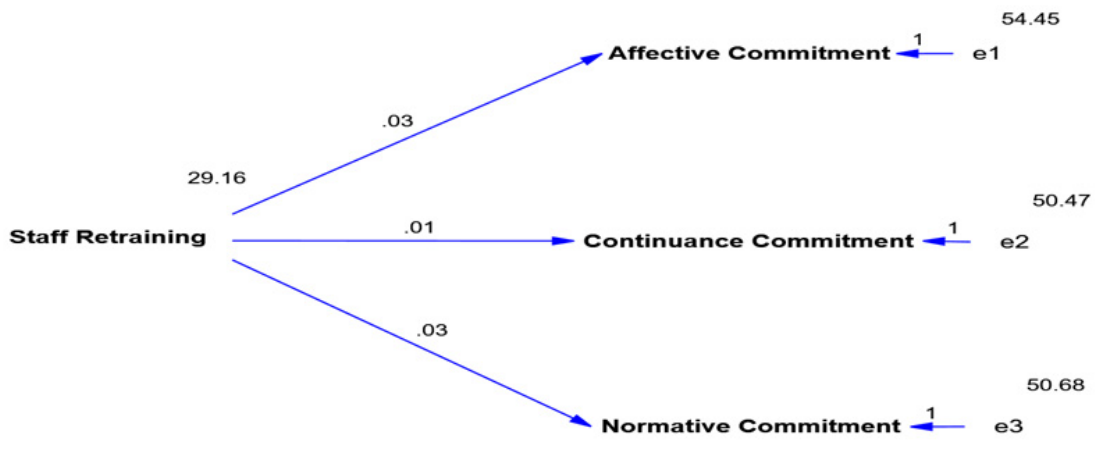

Figure 3: Path diagram showing the contribution of staff retraining to secondary school instructors' job commitment across the three dimensions

Source: Author's computation 


\subsection{Research question three}

To what degree does staff motivation predict job commitment (across the three facets) among secondary school instructors? The results in Fig.4 disclosed that staff motivation contributed about $46 \%, 41 \%$ and $9 \%$ to the total variance in secondary educators' affective, continuance and normative job commitment. This implies that the rate of contribution of staff motivation is higher for the affective dimension, continuance and normative dimensions in that order. This result suggests that other independent variables (with staff motivation as an exception) can be held responsible for the remaining $54 \%, 59 \%$ and $91 \%$ of the total variance in the three aspects of job commitment.

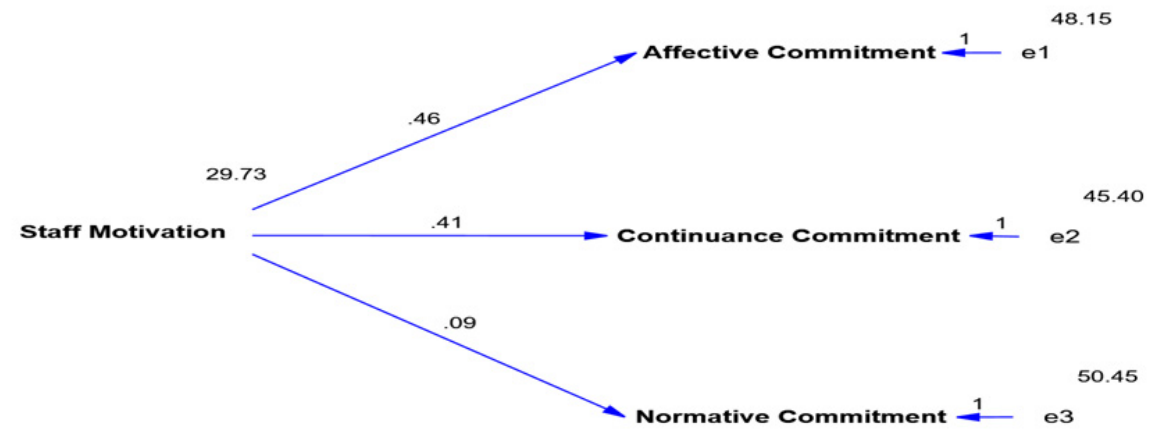

Figure 4: Path diagram showing the contribution of staff motivation to secondary school instructors' job commitment across the three dimensions

Source: Author's computation

\subsection{Research question four}

What is the combined impact of staff placement, retraining and motivation on the job commitment (across the three facets) of secondary school instructors? The result of the analysis presented in the path diagram (Fig.5) reveals that the three predictors (staff placement, retraining and motivation) jointly accounted for the total variance in secondary educators' affective, continuance and normative commitment by $12 \%, 11 \%$ and $1 \%$ respectively. This result indicates that apart from the three predictors variables (staff placement, retraining and motivation), other extraneous variables not studied could be held accountable for the remaining $88 \%, 89 \%$ and $99 \%$ respectively, of the total variance in secondary educators' affective, continuance and normative job commitment. 


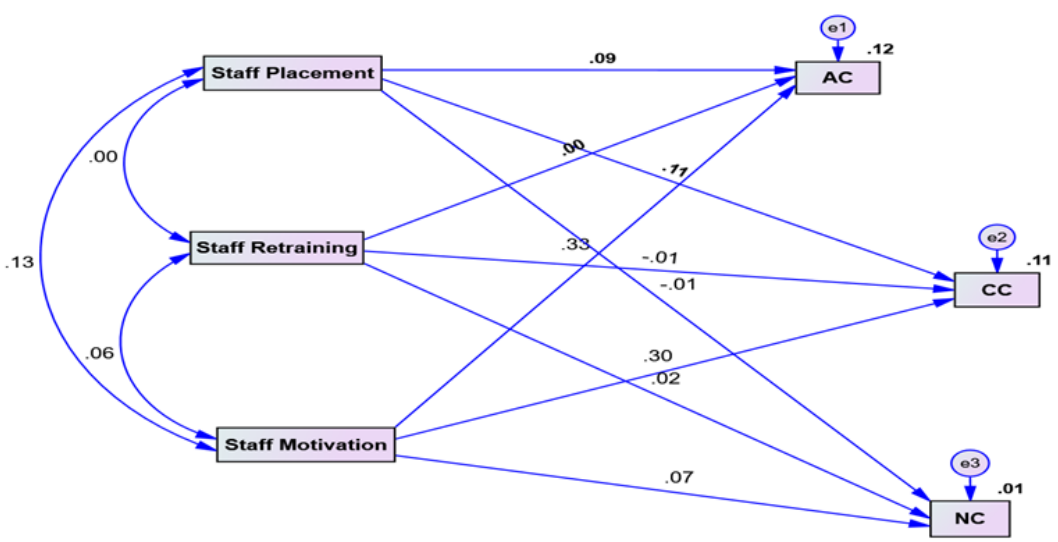

Figure 5: Path diagram showing the composite contribution of staff placement, retraining and motivation to secondary school instructors' job commitment across the three dimensions

Source: Author's computation

Hypothesis 1: The first null hypothesis of this study states that there are no significant partial effects of staff placement, retraining and motivation on secondary school instructors' job commitment across the three dimensions. Alternatively, this hypothesis states that there are significant partial effects of staff placement, retraining and motivation on secondary school instructors' job commitment across the three dimensions. A careful observation of the result in Table 1 , shows that there is a significant effect of staff placement on secondary educators' affective commitment at the .05 level of significance $(\beta=.093, t=2.190, p=.029)$. Staff retraining has no significant effect on secondary educators' affective commitment $(\beta=.003, t=.065, p=$ .948). Staff motivation was revealed to have a significant effect on the affective dimension of secondary educators' job commitment at the .01 alpha level $(\beta=.326, t=$ $7.700, p=.000)$. The result also indicates that staff placement has a significant effect on the continuance dimension of secondary educators' job commitment at the .05 level of significance $(\beta=.112, t=2.640, p=.008)$. Staff retraining has no significant effect on the continuance job commitment of secondary educators $(\beta=-.008, t=-.183, p=.855)$. Staff motivation has a significant effect on the continuance job commitment of secondary educators' $(\beta=.301, t=7.054, p=.000$ ). For the normative dimension of secondary educators' job commitment, the result in Table 1 reveals that staff placement $(\beta=-.013, t=-295, p=.768)$, staff retraining $(\beta=.020, t=.437, p=.662)$ and staff motivation $(\beta=.071, \mathrm{t}=.1 .573, \mathrm{p}=.116)$ are not significant predictors. 
Table 1: Partial effects of staff placement, retraining and motivation on secondary school instructors' job commitment across the three dimensions

\begin{tabular}{lllllllll}
\hline Job commitment & Paths & Predictors & $\beta$ & SE & t & P & Label \\
\hline Affective & $<---$ & Staff Placement & .093 & .058 & 2.190 & $.029^{* *}$ & W9 \\
Affective & $<---$ & Staff Retraining & .003 & .057 & .065 & .948 & W3 & W8 \\
Affective & $<---$ & Staff Motivation & .326 & .058 & 7.700 & $* * *$ & $.058^{* *}$ & W5 \\
Continuance & $<---$ & Staff Placement & .112 & .056 & 2.640 & .007 & W2 \\
Continuance & $<---$ & Staff Motivation & .301 & .056 & 7.054 & $* * *$ & .054 \\
Continuance & $<---$ & Staff Retraining & -.008 & .056 & -.183 & .855 & W7 \\
Normative & $<---$ & Staff Retraining & .020 & .059 & .437 & .662 & W4 \\
Normative & $<---$ & Staff Motivation & .071 & .059 & 1.573 & .116 & W6 \\
Normative & $<---$ & Staff Placement & -.013 & .059 & -.295 & .768 & W1 \\
\hline
\end{tabular}

**Significant at the .05 alpha level

$* * *$ Significant the at the .01 alpha level

Hypothesis 2: The second null hypothesis of this study states that the composite effect of staff placement, retraining and motivation on secondary school instructors' job commitment (across the three facets) is not statistically significant. In its alternative form, this hypothesis states that the composite effect of staff placement, retraining and motivation on secondary school instructors' job commitment (across the three facets) is statistically significant. The result of the multiple regression analysis indicates that the composite effect of staff placement, retraining and motivation is statistically significant on the affective dimension of secondary educators' job commitment $(F[3,496]=$ $23.502, p<.05$ ). The placement, retraining and motivation of employees also have a significant composite effect on the continuance component of secondary instructors' work commitment $(F[3,496]=21.024, p<.05)$. However, there is no significant composite effect of the three predictor variables on the normative dimension of secondary educators' job commitment $(F[3,496]=0.932, p>.05)$. Based on the results presented on the path diagram (Fig. 5) and Table 2, the following regression equations (models) of this study were derived.

$$
\begin{aligned}
& Y^{1}=11.04+0.1265 P+0.0037 R+0.4454 M \\
& Y^{2}=12.10+0.1477 P-0.0102 R+0.3953 M \\
& Y^{3}=18.63-0.0175 P+0.0258 R+0.0936 M \\
& \text { Where: } \\
& Y 1=\text { Affective job commitment } \\
& Y 2=\text { Continuance job commitment } \\
& Y 3=\text { Normative job commitment } \\
& P=\text { Staff placement } \\
& R=\text { Staff retraining } \\
& M=\text { Staff motivation }
\end{aligned}
$$


Table 2: Multiple regression summary showing the composite effect of staff placement, retraining and motivation on secondary school instructors' job commitment across the three dimensions

\begin{tabular}{|c|c|c|c|c|c|c|}
\hline Job Commitment & Source & SS & $\mathrm{df}$ & MS & $\mathrm{F}$ & Sig. \\
\hline Affective & $\begin{array}{l}\text { Regression } \\
\text { Residual } \\
\text { Total }\end{array}$ & $\begin{array}{l}3390.000 \\
23847.928 \\
27237.928\end{array}$ & $\begin{array}{l}3 \\
496 \\
499\end{array}$ & $\begin{array}{l}1130.000 \\
48.081\end{array}$ & 23.502 & $.000^{\mathrm{b}}$ \\
\hline Continuance & $\begin{array}{l}\text { Regression } \\
\text { Residual } \\
\text { Total }\end{array}$ & $\begin{array}{l}2847.306 \\
22391.196 \\
25238.502\end{array}$ & $\begin{array}{l}3 \\
496 \\
499\end{array}$ & $\begin{array}{l}949.102 \\
45.144\end{array}$ & 21.024 & $.000^{\mathrm{b}}$ \\
\hline Normative & $\begin{array}{l}\text { Regression } \\
\text { Residual } \\
\text { Total }\end{array}$ & $\begin{array}{l}142.173 \\
25211.545 \\
25353.718\end{array}$ & $\begin{array}{l}3 \\
496 \\
499\end{array}$ & $\begin{array}{l}47.391 \\
50.830\end{array}$ & .932 & $.425^{\mathrm{b}}$ \\
\hline
\end{tabular}

a. Dependent Variables: Affective, Continuance and Normative Job Commitment

b. Predictors: (Constant), Staff Motivation, Retraining and Placement

The researchers tested for the presence of auto-correlation to be sure that the result obtained was not due to high correlations among the predictor variables. This is shown in Fig. 6, which reveals that the independent variables did not correlate highly amongst themselves. This implies that the multiple regression models of this study (denoted by equations 1 to 3 above) are acceptable.

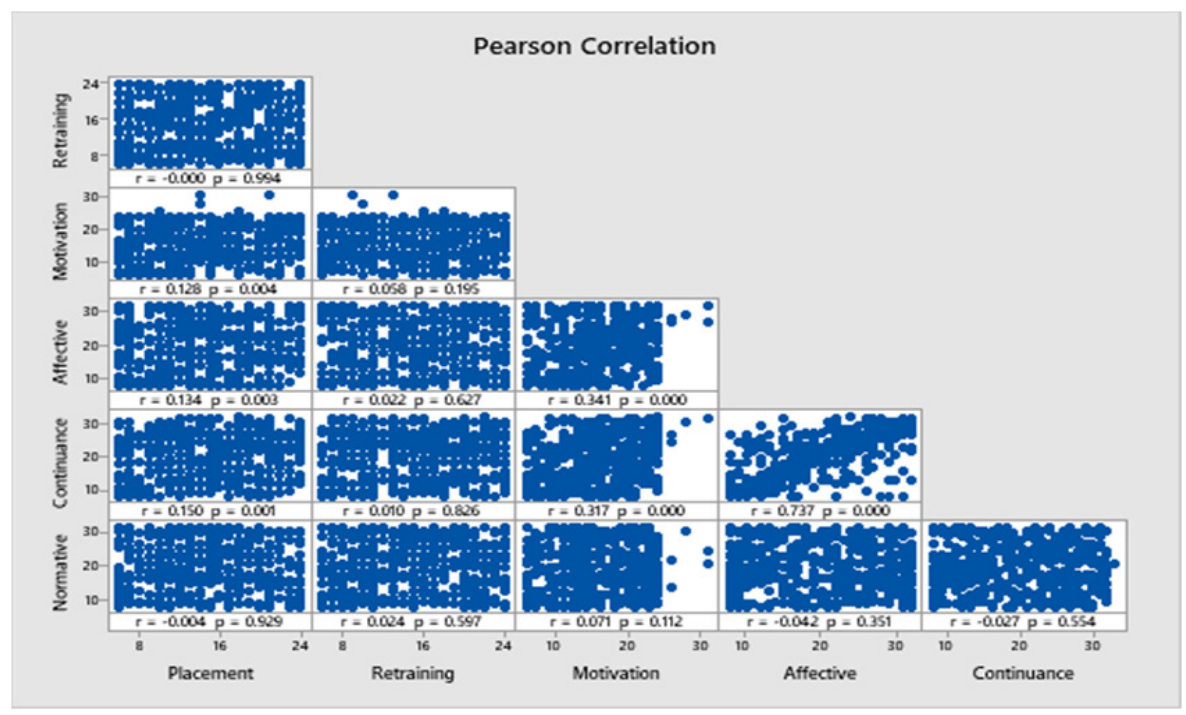

Figure 6: Pearson correlation matrix of the variables used in this study Source: Author's computation 


\section{Discussion of Findings}

\subsection{Staff placement and job commitment}

It was discovered in this study that the extent staff placement contributed to the affective, continuance and normative job commitment of secondary educators' is below average (less than 50\%) across the three dimensions. However, the contribution of staff placement was significant in promoting the affective and continuance but not the normative job commitment of secondary educators. This finding may be attributed to the excitement that follows the performance of tasks individuals are skilled at doing (Ronfeldt, 2015). An employee may become bored and emotionally worried about performing task $\mathrm{s} /$ he has little competence or skills to handle. This may raise tension levels, making them collaborate less, search for or wish that greener pastures are available for a switch. The result may have been insignificant in the normative dimension perhaps due to the contractual terms binding workers to organisations, such that their interest to either stay or leave the organisation is based on the ties in the contract.

This finding aligns with the three-component theory of Allen and Meyer (1990) that individuals can stay in an organisation because they ought to; because they want to; because they have to. Therefore, if an employee considers his/her placement as being favourable or otherwise, s/he may take actions at the affective and continuance aspects (i.e., stay with the organisation, if emotionally attached or just because of available benefits; leave the organisation, if not emotionally attached or based on better offers). For the third aspect (normative), an individual seeking to leave an organisation for being wrongly assigned a job to perform (or other reasons) may be forced to stay back if the contract tenure is yet to elapse. This finding aligns also with previous studies (AjaOkorie, 2016; Okoroji \& Anyanwu, 2013) which revealed also that teachers' placement predicts teachers' efficiency.

\subsection{Staff retraining and job commitment}

The second major finding of this investigation shows that staff retraining contributed to a very low extent to secondary educators' affective, continuance and normative job commitment. The rate of contribution is so low that it was statistically proven to be insignificant in exerting any effect on secondary educators' job commitment across the three dimensions (affective, continuance and normative). The insignificance of the effect of staff retraining on educators' job commitment may be attributed to the school climate where educators are delivering services. Retraining of staffers equip them with the necessary skills to perform their job well (Aboyassin \& Sultan, 2017; Arop et al., 2019; Owan, 2018); however, it becomes useless if employees are offered retraining opportunities without strong climatic support to utilise or implement these skills. Based 
on the three-component model (Allen \& Meyer, 1990), job commitment is about employees' retention or attrition.

A well-trained staff may switch to another organisation notwithstanding, if for instance, the personnel finds a "greener pasture" elsewhere (continuance commitment); the personnel is unhappy with the organisation, is emotionally detached from it and thinks $\mathrm{s} /$ he would derive more satisfaction elsewhere, etc (affective commitment); the worker is out of contract or is highly pressured to leave the organisation based on either all or one of the first two reasons (normative commitment). It can be seen through the results of this study that staff retraining harms commitment suggesting that the retraining of employees tends to take them away from organisations. This may be true because the more skills and knowledge individuals possess, the higher the rate of competitors that would seek their services with better offers (see Muysken \& Weel, 1999; Schlicht, 1981). Therefore, firms who are not able to stir up affective and continuance job commitment levels in their workers stand a chance of losing them after retraining them.

\subsection{Staff motivation and job commitment}

Through the third major finding of this study indicates that staff motivation contributed near average to secondary educators' affective and continuance job commitment. However, the rate of contribution was low on the normative dimension of job commitment. Furthermore, the impact of staff motivation is substantial on both the affective and continuance aspects of instructors' commitment, but negligible on the normative component. This result is not shocking given that motivation plays an important role in forming relationships between workers and their organizations (Nohria et al., 2008; Leea \& Raschkeb, 2016); and has the potential to elicit affective engagement.

The use of motivational tools such as rewards, praises, recognition, fringe benefits (especially if backed with good salary rates) for employees, makes it very difficult for other suitors/competitors/employers to tempt them away from an organisation (continuance commitment). Conversely, the partial presence or total absence of motivational packages and activities promote poor performance and mental health (Bean, 2018), which may give employees easy decisions to swap one organisation for another. It is worrisome also that motivation has no significant effect on educators' normative commitment. However, it is quite revealing that an employee without any job offer elsewhere may be willing to commit to an organisation that motivates poorly if that is the only means to livelihood (socio-economic-pressure-induced commitment). Where a contract is involved and the employee is not allowed to terminate it, poor motivation can still promote job commitment (normative commitment in this case). 


\subsection{Staff placement, retraining, motivation and job commitment}

Taken together, this study discovered that staff placement, retraining and motivation jointly accounted for low rates of variance in secondary educators' affective, continuance and normative commitment. The three predictors variables were statistically significant in causing a change in the affective and continuance job commitment of secondary educators. However, they were not significant factors in predicting the normative commitment of secondary educators. This finding implies that schools that place teachers appropriately, retrains them often and motivate them using appropriate tools/channels are more likely to promote the emotional attachment of workers (see Berridge, 2018; Chraifa \& Aniteib, 2012; Sincero, 2012); giving them a reason to stay in the organisation amidst competition. However, this rule does not hold with the normative component of educators' job commitment. This may be attributed to employee job satisfaction, social pressures, attitudes of co-workers, lack of contentment or other factors (not studied) that may cause employees to leave a wellpaying job, with adequate incentives and climate for something less or better. In case of a contract, it is possible that employees may also be relieved of their duties by employers if the tenure of contract elapses (making workers' willingness to work in an organisation with good placement, retraining and motivation schemes to be truncated).

\section{Limitations of the Study}

This study, notwithstanding its exciting findings, is characterised by a few limitations (typical of any study). First, the study targeted respondents from a relatively small geographical area in a developing country (Nigeria). The generalisations made may apply to the area of study or at best to developing nations. Therefore, prospective researches in this area are necessary for developed nations for comparative purposes. Secondly, the study was not able to explain the reasons why the presence of placement, retraining and motivation would not promote the normative commitment of secondary educators. The study only suspects some extraneous variables which should be considered in prospective studies. Lastly, there are many other correlates of employee job commitment that were not considered in this study, only three were studied.

\section{Conclusion/Recommendations}

Based on the findings of this study it was concluded that some staff personnel management practices are critical in promoting teachers' commitment in secondary schools. Staff motivation is the most powerful tool that can be used to boost secondary educators' affective and continuance job commitment, followed by employee placement. Merely retraining staff is not significant enough to promote job commitment at the affective, continuance and normative dimensions, but would yield positive and 
significant results in the presence of other will-boosting predictors such as staff placement and motivation. Staff retraining, if not backed with a strong motivational and placement practice would likely lead to the extinction of many secondary educators. This is because, such retraining opportunities boost the manpower of workers for better service delivery, which has the potentials of attracting many competitors and employers.

Thus, only schools with strong affectively committed personnel, with adequate motivational grounds (which boost employees continuance commitment) can retain workers under fierce competition. The school administrator role is to ensure that these personnel management services are adequately provided to ensure that secondary teachers discharge their duties maximally for optimal results to be obtained in the future. Based on the conclusion of the study, the following recommendations were made:

i. Teachers should be assigned duties based on their ability, competence, and specialization at all times. Where two equities are equal, the teacher with the highest enthusiasm should be assigned tasks to promote effective attitudes in the discharge of duties.

ii. The government should ensure that only professionally trained teachers are allowed to teach in secondary schools. There should be frequent re-training opportunities for teachers based on the societal dynamics for a sustained teaching workforce.

iii. Secondary school administrators should ensure that staff are adequately retrained to gain mastery of skills for improved work performance and service delivery; but to promote the affective and continuance job commitment of educators, such retraining should be followed with consistent motivational practices.

iv. There should be a regular promotion, consistent payment of teachers' salaries and other incentives to deserving teachers for improved work performance and commitment. Teachers with outstanding performance can also be rewarded through praises of the mouth and gifts.

v. Further research should be conducted to explore factors responsible for employee resistance to normative commitment in the presence of adequate motivation and appropriate job placement in secondary education.

\section{References}

Aboyassin, N. A., \& Sultan, M. A. (2017). The role of human resources training in improving the employees' performance: Applied study in the five stars hotels in Jordan. International Journal of Business Administration, 8(5), 46-56. https://doi.org/10.5430/ijba.v8n5p46

Agunwa, J. N., Owan, V. J., \& Ekpe, M. B. (2019). Personnel management: Implications for the effectiveness of the school system. International Journal of Research and Innovation in Social Science (IJRISS), 3(10), 391-395. https://tinyurl.com/wktu32q 
Aja-Okorie, U. (2016). Teachers personnel management as a determinant of teacher productivity in secondary schools in Delta State, Nigeria. British Journal of Education, 4(8), 13-23. https://bit.ly/3ecZKI1

Aja-Okorie, U., \& Usulor, V. I. (2016). Analysis of principals' motivational practices for teachers' effectiveness in public and private secondary schools in Ebonyi State, Nigeria. Public Policy and Administration Research, 6(2), 74-83. https://bit.ly/38FFopQ

Ali, A. Y. S., Dahie, A. M. \& Ali, A. A. (2016). Teachers' motivation and school performance, the mediating effect of job satisfaction: Survey from secondary schools in Mogadishu. International Journal of Education and Social Science, 3(1), 24-38. https://bit.ly/38MX6HR

Allen, N. J., \& Meyer, J.P. (1990). The measurement and antecedents of affective, continuance and normative commitment to the organization. International Journal of Occupational Psychology, 63, 1-18. https://bit.ly/208TDdl

Arop, F. O., Owan, V. J., \& Ekpang, M. A. (2018). Administrators' conflict management strategies utilization and job effectiveness of secondary school teachers in Obubra Local Government Area, Cross River State, Nigeria. IIARD International Journal of Economics and Business Management, 4(7), 11-21. https://doi.org/https://goo.gl/LcP61t

Arop, F. O., Owan, V. J., \& Madukwe, E. C. (2019). Human resource management and teachers' job performance in secondary schools in Akamkpa Local Government Area of Cross River State, Nigeria. International Journal of Social Sciences and Management Research, 5(2), 27-34. https://goo.gl/TjSrAe

Bartlett, K. R. (2001). The relationship between training and organizational commitment: A study in the health care field. Human Resource Development Quarterly, 12, 335-352. https://doi.org/10.1002/hrdq.1001

Bean, S. (2018). Lack of motivation at work impacts both performance and mental health. https://bit.ly/3ejA5NR

Berridge, K. C. (2018). Evolving concepts of emotion and motivation. Frontiers in Psychology, 9, 1647. https://doi.org/10.3389/fpsyg.2018.01647

Biwott, G. K., \& Kemboi, A. K. (2017). Does employee work-life policies and empowerment strategies drive employee commitment? Kenyan perspective, synergy approach. International Journal of Business and Management Review, 4(1), 55-78l. https://bit.ly/2Dtg2jq

Chraifa, M., \& Aniteib, M. (2012). Attachment, motivation, positive and negative emotions and support groups as predictors of Romanian students' career orientation in psychology. Procedia-Social and Behavioral Sciences, 46, 2409-2413. https://doi.org/10.1016/j.sbspro.2012.05.494

Cobblah, M. A. (2015). The contribution of staff training and development programmes to effective library and information services in selected university libraries in Ghana. PhD. Dissertation (University of South Africa). https://bit.ly/3iO5dZr

Degraft, O. E. (2012). The effect of training and development on employee performance at Accra polytechnic. M.Ed. Thesis (Institute of Distance Learning, Kwame Nkrumah University of Science and Technology). https://bit.ly/3egPtug

Essien, E. E., Okon E. A., \& Obot, I. M. (2016). The influence of in-service training, seminars and workshops attendance by social studies teachers on academic performance of students in junior secondary schools in Cross River State, Nigeria. Journal of Education and Practice, 7(22), 31-35. https://bit.ly/2ZTUGmW

Ezeugbor, C. O., Onyali, L. C., \& Okoye, F. O. (2018). Staff personnel administrative practices adopted by principals' for promoting teacher-job performance in secondary schools in Awka Education Zone, Anambra State, Nigeria. International Journal of Advanced Research and Publications, 2(1), 20-26. https://bit.ly/3ehEd11

Gunu, U., Oni, E., Tsado, E., \& Ajayi, O. (2013). Empirical study of training and development as a tool for organizational performance: A case study of selected banks in Nigeria. Arabian Journal of Business and Management Review, 2(10), 78-87. https://bit.ly/38L8GTK

Hashmi, K. (2014). Human resource management strategies and teacher's efficiency within schools: A co-relational study. IAFOR Journal of Education, 2(1), 65-86. https://doi.org/10.22492/ije.2.1.03

Idaka I. I., \& Anagbogu, G. (2012). Research design. In Isangedighi, A. J. (Ed). Essentials of research and statistics in education and social sciences (pp. 65-79). Calabar: Eti-Nwa Associates.

Khaerudin, T., Rivai, A., \& Riyanto, M. (2018). The effect of placement and competency on performance through employee commitment in the financial centre office, Ministry of Defense, Indonesia. IOSR Journal of Business and Management (IOSR-JBM), 20(2),54-61. https://doi.org/10.9790/487X-2002085461

Kwapong, L. S. A., Opoku, E., \& Donyina, F. (2015). The effect of motivation on the performance of teaching staff in Ghanaian polytechnics: The moderating role of education and research experience. Global Journal of Human Resource Management, 3(6), 30-43. https://bit.ly/2Dw6IRr

Leea, M. T., \& Raschkeb, R. L. (2016). Understanding employee motivation and organizational performance: Arguments for a set-theoretic approach. Journal of Innovation \& Knowledge, 1(3), $162-169$. https://doi.org/10.1016/j.jik.2016.01.004

Mackenzie, C. P., \& Nwafor, S. O. (2019). In-service training and job security as determinants of teachers' job commitment in public senior secondary schools in Abia State. International Journal of Education and Evaluation, 5(7), 12-24. https://bit.ly/3ekk5ep 
Muysken, J., \& Weel, B. (1999). Overeducation, job competition and unemployment. Paper Presented at the European Association of Labour Economists Annual Conference, Regensburg, Germany, 23-26 September. https://bit.ly/3epTo8w

Nairuba, J. (2004). Motivational practices and teachers' performance in Jinja Municipality secondary schools, Jinja District, Uganda. Master's Thesis (Bugema University, Kampala). https://bit.ly/3gLzsyo

Naong, T. (2016). The moderating effect of skills development transfer on organizational commitment - A case-study of Free State TVET colleges. Problems and Perspectives in Management, 14(4), $159-169$. https://doi.org/10.21511/ppm.14(4-1).2016.04

Nohria N, Groysberg B, \& Lee, L. E. (2008). Employee motivation: A powerful new model. Harvard Business Review, 86(78), 78-160. https://bit.ly/3ejC7NZ

Nwadiani, M. (2008). Education in foreign countries: Lessons for policy planning and practice. Monose Amalgamates Publishers.

Ocen, E., Francis, K., \& Angundaru, G. (2017), The role of training in building employee commitment: the mediating effect of job satisfaction. European Journal of Training and Development, 9, 742-757. https://doi.org/10.1108/EJTD-11-2016-0084

Ofoegbu, F. I. (2004). Teacher motivation: A factor in classroom effectiveness and school improvement in Nigeria. Project Innovation Publishers.

Okoroji, L. I., \& Anyanwu, J. O. (2013). The relationship between the placement of female teachers and the academic performance of secondary school students in Owerri Urban of Imo State. Journal of Literature, Languages and Linguistics, 2(1), 20-34. https://bit.ly/3e9DwXu

Omebe, S. E. (2005). Guidance and counselling: A comprehensive approach. Cheston Agency Ltd.

Omorobi, G. O., Mbon, U. F., Owan, V. J., \& Ekpenyong, J. A. (2020). Participative management practices and institutional goal attainment in Nigerian universities. American Journal of Social Sciences and Humanities, 5(1), $169-177$. https://doi.org/10.20448/801.51.169.177

Owan, V. J. (2018). Conflict management strategies and secondary school teachers' job effectiveness in Obubra Local Government Area of Cross River State, Nigeria. B.Ed. Project (University of Calabar, Nigeria). https://doi.org/10.13140/RG.2.2.35015.55200

Owan, V. J., \& Agunwa, J. N. (2019). Principals' administrative competence and teachers' work performance in secondary schools in Calabar Education Zone of Cross River State, Nigeria. Humanities and Social Sciences Letters, 7(1), 20-28. https://doi.org/10.18488/journal.73.2019.71.20.28

Owan, V. J., Bassey, B. A., Mbon, U. F., Okon, A. E., Ene, O. E., Ekaette, S. O., Ojong, C. O., \& Ekpe, M. B. (2020). Validation of an instrument and measurement of employee work-life policies, psychological Empowerment, and job commitment of academic staff in universities. Mediterranean Journal of Social Sciences, 11(2), 86-100. https://doi.org/10.36941/mjss-2020-0022

Owan, V. J., Duruamaku-dim, J. U., Ekpe, M. B., Owan, T. J., \& Agurokpon, D. C. (2019). School characteristics and secondary school teachers' work effectiveness in Abi Local Government Area of Cross River State. American Journal of Education and Information Technology, 3(1), 25-31. https://doi.org/10.11648/j.ajeit.20190301.15

Owan, V. J., Nwannunu, B. I., \& Madukwe, E. C. (2018). Problems of school management and students' academic performance in secondary schools in Calabar Education Zone, Cross River State, Nigeria. International Journal of Research and Innovation in Social Science (IJRISS), 2(10), 120-127. https://bit.ly/2Zd5HAA

Owusu, T. (2012). Effects of motivation on employee performance: A case study of Ghana commercial bank, Kumasi zone. M.Ed. Thesis (Kwame Nkrumah University of Science and Technology). https://bit.ly/3fhd67w

Peretomode, V. F., \& Bello, S. O. (2018). Analysis of teachers' commitment and dimensions of organizational commitment in Edo State public secondary schools. Journal of Educational and Social Research, 8(3), 87 - 92. https://doi.org/10.2478/jesr-2018-0034

Romina, I. A. (2016). Relational study of in-service training, teaching effectiveness and academic performance of students. Journal of Teaching and Education, 5(2), 205-216. https://bit.ly/2W3QC2h

Ronfeldt, M. (2015). Field placement schools and instructional effectiveness. Journal of Teacher Education, 66(4), 304320. https://doi.org/10.1177/0022487115592463

Sari, P. A., \& Sa'adah, P. N. (2019). Work placement, organizational commitment and employee performance: Evaluation of public service offices in Indonesia. Review of Behavioural Aspect in Organizations and Society, 1(2), $129-140$. https://doi.org/10.32770/rbaos.vol1129-140

Schlicht, E. (1981). Training costs and wage differentials in the theory of job competition. Journal of Institutional and Theoretical Economics, 137(2), 212-221. https://bit.ly/2ZWhCSA

Sincero, S. M. (2012). Motivation and emotion. https://explorable.com/motivation-and-emotion

Tukunimulongo, J. (2016). Effect of on-the-job training on employee performance in Kenya: Case of Mumias Sugar Company Limited. International Journal of Recent Research in Commerce Economics and Management, 3(1), 7-24. https://bit.ly/2W77mWt 
Udofia, U. I., \& Ikpe, U. N. (2012). Administration of in-service training and teachers' attitude to work in private secondary schools in Cross River State of Nigeria. International Journal of Academic Research in Business and Social Sciences, 2(10), 305-311. https://bit.ly/2Cp4PQ9

Uso, E. B. (2011). The influence of motivation on teachers' efficiency in secondary schools in Biase local government area of Cross River State. B.Ed. Project (University of Calabar, Calabar, Nigeria). 